\title{
The skin prick test - European standards
}

\author{
Lucie Heinzerling $^{1 *}$, Adriano Mari ${ }^{2}$, Karl-Christian Bergmann ${ }^{3}$, Megon Bresciani $^{4}$, Guido Burbach ${ }^{3}$, Ulf Darsow $^{5}$, \\ Stephen Durham ${ }^{6}$, Wytske Fokkens ${ }^{7}$, Mark Gjomarkaj ${ }^{8}$, Tari Haahtela ${ }^{9}$, Ana Todo Bom ${ }^{10}$, Stefan Wöhrl ${ }^{11}$, \\ Howard Maibach ${ }^{12}$ and Richard Lockey ${ }^{13}$
}

\begin{abstract}
Skin prick testing is an essential test procedure to confirm sensitization in lgE-mediated allergic disease in subjects with rhinoconjunctivitis, asthma, urticaria, anapylaxis, atopic eczema and food and drug allergy. This manuscript reviews the available evidence including Medline and Embase searches, abstracts of international allergy meetings and position papers from the world allergy literature. The recommended method of prick testing includes the appropriate use of specific allergen extracts, positive and negative controls, interpretation of the tests after $15-20$ minutes of application, with a positive result defined as a wheal $\geq 3 \mathrm{~mm}$ diameter. A standard prick test panel for Europe for inhalants is proposed and includes hazel (Corylus avellana), alder (Alnus incana), birch (Betula alba), plane (Platanus vulgaris), cypress (Cupressus sempervirens), grass mix (Poa pratensis, Dactilis glomerata, Lolium perenne, Phleum pratense, Festuca pratensis, Helictotrichon pretense), Olive (Olea europaea), mugwort (Artemisia vulgaris), ragweed (Ambrosia artemisiifolia), Alternaria alternata (tenuis), Cladosporium herbarum, Aspergillus fumigatus, Parietaria, cat, dog, Dermatophagoides pteronyssinus, Dermatophagoides farinae, and cockroach (Blatella germanica). Standardization of the skin test procedures and standard panels for different geographic locations are encouraged worldwide to permit better comparisons for diagnostic, clinical and research purposes.
\end{abstract}

Keywords: Sensitization, Inhalant allergens, Skin prick test panel, Aallergies, Type I allergy, Diagnostic test, Asthma

Skin prick testing (SPT) is a reliable method to diagnose IgE-mediated allergic disease in patients with rhinoconjunctivitis, asthma, urticaria, anapylaxis, atopic eczema and suspected food and drug allergy. It provides evidence for sensitization and can help to confirm the diagnosis of a suspected type I allergy. It is minimally invasive, inexpensive, results are immediately available and when carried out by trained health professionals, reproducible. Since the first publication about SPT by Helmtraud Ebruster in 1959 [1], who extensively researched this diagnostic test, it has been used as a primary diagnostic tool to detect type I hypersensitivity reactions. Although the principle of SPT still largely resembles the original methods described, a wide array of interpretations and modifications has led to diminished comparability when SPT results are reported. In

\footnotetext{
* Correspondence: lucie.heinzerling@uk-erlangen.de

${ }^{1}$ Department of Dermatology, University Hospital Erlangen, 91054 Erlangen, Germany

Full list of author information is available at the end of the article
}

addition, the different kind of extracts used in various countries makes comparison of data difficult.

The Global Allergy and Asthma European Network $\left(\mathrm{GA}^{2} \mathrm{LEN}\right)$ is a network of research investigators formed to augment the cooperation of allergy and asthma research throughout Europe. The purpose of the $\mathrm{GA}^{2} \mathrm{LEN}$ quality management is to standardize procedures used to diagnose and treat allergic diseases. A survey was conducted to assess SPT practices at the different participating centres at the debut of the program. Although there were similarities in technique for SPT, e.g., the use of positive and negative controls and requesting information from the patient about medications that could interfere with test results, there were also striking differences [2]. These investigators realized that standardization of SPT procedures is desirable so that findings from clinical practice and research become more comparable. Therefore, a GA ${ }^{2}$ LEN protocol was developed using a common panel of inhalant allergens (Table 1) and a standard operating procedure to perform and appropriately interpret SPT results based on published practice
C Biomed Central

(c) 2013 Heinzerling et al.; licensee BioMed Central Ltd. This is an Open Access article distributed under the terms of the Creative Commons Attribution License (http://creativecommons.org/licenses/by/2.0), which permits unrestricted use, distribution, and reproduction in any medium, provided the original work is properly cited. 
Table 1 Standard prick test panel for inhalant allergens

\begin{tabular}{|c|c|}
\hline \multicolumn{2}{|c|}{ Allergen/control } \\
\hline \multicolumn{2}{|c|}{$\begin{array}{l}\text { Histamindihydrochloride } 0,1 \\
\% \text { (positive control) }\end{array}$} \\
\hline \multicolumn{2}{|c|}{$\begin{array}{l}\mathrm{NaCl} 0.9 \% \text { (negative } \\
\text { control) }\end{array}$} \\
\hline Hazel & Corylus avellana \\
\hline Alder & Alnus incana \\
\hline Birch & Betula alba \\
\hline Plane & Platanus vulgaris \\
\hline Cypress & Cupressus sempervirens \\
\hline Grass mix & $\begin{array}{l}\text { smooth meadow grass/Poa pratensis, } \\
\text { cock's foot grass/Dactilis glomerata, } \\
\text { perennial rye grass/Lolium perenne, } \\
\text { timothy grass/Phleum pratense, meadow } \\
\text { fescue/Festuca pratensis, meadow oat } \\
\text { grass/Helictotrichon pretense }\end{array}$ \\
\hline Olive & Olea europaea \\
\hline Mugwort & Artemisia vulgaris \\
\hline Ragweed & Ambrosia artemisiifolia \\
\hline Alternaria & Alternaria alternata (tenuis) \\
\hline Cladosporium & Cladosporium herbarum \\
\hline Aspergillus & Aspergillus fumigatus \\
\hline Parietaria & Parietaria \\
\hline \multicolumn{2}{|l|}{ Cat } \\
\hline \multicolumn{2}{|l|}{ Dog } \\
\hline \multicolumn{2}{|c|}{$\begin{array}{l}\text { Dermatophagoides } \\
\text { pteronyssinus }\end{array}$} \\
\hline \multicolumn{2}{|c|}{ Dermatophagoides farinae } \\
\hline Blatella & Blatella germanica \\
\hline
\end{tabular}

guidelines, the European Academy of Allergy and Clinical Immunology (EAACI) Position Paper, the Nordic standards and the International Study of Asthma and Allergies in Childhood (ISAAC) phase II protocol. The large multicenter GA ${ }^{2}$ LEN study was carried out in 17 centers in 14 countries and showed that a proposed standard protocol and allergen panel for SPT are feasible [3,4].

\section{Indication for SPT}

SPT is indicated if a type I (immediate type) allergy is suspected, based on the medical history and clinical symptoms; they can identify sensitivity to inhalant, food, drug or occupational allergens. SPTs thus provide objective confirmation of sensitivity, whereas the relevance of such sensitivity to allergens should always be carefully interpreted in the light of the clinical history so that appropriate advice concerning avoidance measures can be given and, as necessary, the correct allergen(s) prescribed for specific immunotherapy (SIT). SPT results correlate with those of nasal challenge which may also be used as a surrogate to test clinically relevant sensitization [5].
Another indication of SPT is to screen for a predisposition to develop atopic diseases, which can be done with a limited number of allergens, or to identify all sensitized subjects in a given population. SPT also can be used in epidemiologic studies to determine trends in sensitization rates or regional differences and to help standardize allergen extracts.

SPT is used to test adults and children from birth onwards. Repeated testing may be necessary in order to detect new sensitizations, especially in children, when symptoms change, or if new environmental allergens are suspected.

\section{General principle in SPT}

SPT interpretation utilizes the presence and degree of cutaneous reactivity as a surrogate marker for sensitization within target organs, i.e., eyes, nose, lung, gut and skin. When relevant allergens are introduced into the skin, specific IgE bound to the surface receptors on mast cells are cross-linked, mast cells degranulate, and histamine and other mediators are released. This produces a wheal and flare response which can be quantitated. Many different allergens can be tested simultaneously because the resultant reaction to a specific allergen is localized to the immediate area of the SPT.

\section{Comparison with other methods}

The chief advantage of SPT as compared to an in vitro measurement of specific IgE antibodies is that the test can be interpreted within 15 to 20 minutes after the reagent is applied to the skin. Moreover, the test gives a visual indication of the sensitivity which can be used in order to impact the patient's behavior. SPT can also be utilized to test less common allergens, such as certain medications, and fresh fruits and vegetables where no specific IgE antibody measurements are available.

The skin scratch test, first described by Blackley in 1873 [6], is not recommended as a test modality for inhalant or food allergens since results are more difficult to interpret and standardize. Scratch testing may result in varying quantities of allergen absorbed, mechanical irritation of the skin [7], bleeding at the test site, and carries a higher risk of inducing a systemic allergic reaction.

The in vitro measurement of specific IgE antibodies [8-10] is an important complementary tool to diagnose type I allergy, especially in subjects who cannot undergo SPT. For example, SPT is not practical in patients who have extensive eczema, dermographism, urticaria, or who are taking antihistamines or other medications which interfere with the proper interpretation of the test results (Table 2). In vitro test methods may be less sensitive $[11,12]$ and/or less specific $[13,14]$ than SPT depending on the method utilized and the allergens 
Table 2 Potential interference of medications with the skin test reaction (adapted from Demoly (2003) [23]; Rueff (2010) [24] and Position Paper: Allergen standardization and skin tests: The European Academy of Allergy (1993))

\begin{tabular}{|c|c|c|c|}
\hline \multirow[t]{2}{*}{ Drug } & Suppression & Abstinence before testing & Reference \\
\hline & \multicolumn{3}{|l|}{$\begin{array}{l}\text { 0: no evidence; (+): possible, } \\
\text { +: slight; ++: medium, } \\
+++: \text { strong }\end{array}$} \\
\hline \multicolumn{4}{|l|}{ Antihistamines } \\
\hline 1st generation $\mathrm{H}$ 1-blocker & +++ & $>2$ days & Dreborg (1989) [25] \\
\hline \multicolumn{4}{|l|}{ Hydroxyzine } \\
\hline 2nd generation $\mathrm{H} 1$-blocker & +++ & 7 days & Devillier (2008) [26] \\
\hline \multicolumn{4}{|l|}{ Cetirizine, Loratadine, etc. } \\
\hline Ketotifen & +++ & $>5$ days & \\
\hline H2-blocker & $0-+$ & $\varnothing$ & \\
\hline \multicolumn{4}{|l|}{ Glucocorticosteroids } \\
\hline Topical (in test area) & + & $>1$ week $^{1}$ & $\begin{array}{l}\text { Hammarlund (1990) [27], } \\
\text { Pipkorn (1989) [28], } \\
\text { Gradman (2008) [29] }\end{array}$ \\
\hline Nasal & 0 & $\varnothing$ & \\
\hline Inhaled & 0 & $\varnothing$ & \\
\hline Systemic/short term (up to 10 days) & $0 /(+)$ & & \\
\hline$<50 \mathrm{mg} / \mathrm{d}$ Prednisolone-equivalent & $0 /(+)$ & $>3$ days & Hammarlund (1990) [30] \\
\hline$>50$ mg/d Prednisolone-equivalent & $(+)$ & $>1$ week $^{2}$ & Des Roches (1996) [31] \\
\hline \multicolumn{4}{|l|}{$\begin{array}{l}\text { Systemic/long term (more than } 10 \\
\text { days) }\end{array}$} \\
\hline$<10$ mg/d Prednisolone-equivalent & 0 & $\varnothing$ & Olson (1990) [32] \\
\hline$>10$ mg/d Prednisolone-equivalent & 0 & $>3$ weeks $^{2}$ & Des Roches (1996) [31] \\
\hline Topical calcineurin inhibitors & + & $>1$ week & Gradman (2008) [29] \\
\hline \multicolumn{4}{|l|}{ Other systemic drugs } \\
\hline Omalizumab & ++ & $>4$ weeks & Noga (2003) [33] \\
\hline Leukotriene receptor antagonist & 0 & $\varnothing$ & Cuhadaroglu (2001) [34], Hill (2003) [35] \\
\hline Cyclosporin A & 0 & $\varnothing$ & Munro (1991) [36] \\
\hline Theophylline & 0 & $\varnothing$ & Spector (1979) [37] \\
\hline \multicolumn{4}{|l|}{ Antidepressants } \\
\hline Doxepin & ++ & 7 days & Rao (1988) [38] \\
\hline Desipramine & ++ & 3 days & Rao (1988) [38] \\
\hline SSRI: Citalopram, Fluoxetin, Sertralin & 0 & $\varnothing$ & Isik (2011) [39] \\
\hline$\beta$-adrenergic agonists & 0 & $\varnothing$ & Abramowitz (1980) [40], Spector (1979) [39] \\
\hline $\begin{array}{l}\text { Salbutamol, Salmeterol, Bambuterol, } \\
\text { Terbutalin }\end{array}$ & 0 & & Petersen (2003) [41] \\
\hline
\end{tabular}

${ }^{1}$ Depends on dosage and length of treatment (> 3 weeks).

${ }^{2}$ A retrospective study showed no influence of the skin reaction by $10-60 \mathrm{mg}$ prednisone for 2 or more years.

employed. Furthermore, in subjects with very high total serum IgE antibodies, low levels of specific IgE antibodies of doubtful clinical relevance are often detected. Concordance between in vitro specific IgE antibody assays and SPT results is between $85 \%$ and $95 \%$, depending on the allergen being tested [15-18] and the method used to detect specific IgE [19-21]. In a study of over 8000 subjects, SPT versus quantitation of specific IgE antibodies, for example, with the CAP FEIA technology (Phadiatop ${ }^{\circledR}$, Pharmacia, Uppsala, Sweden), had the best positive predictive value to determine clinical allergy for respiratory allergic diseases [22]. Moreover, SPT provides 
immediate information versus in vitro test results which may not be available for days or weeks. Thus, SPT has greater flexibility and is usually less costly.

Intradermal skin tests are more sensitive but less specific than SPT [42]. They are more labor-intensive and require more precise techniques. These tests have occasionally been associated with serious systemic allergic reactions and even death from anaphylaxis [43,44]. In clinical practice, SPT tests should always be performed first since a positive test circumvents the necessity for intradermal skin testing. Extracts utilized for intradermal skin testing are less concentrated (1:10-1:1000; 0.00001 $\mu \mathrm{g} / \mathrm{ml}$ up to $1 \mu \mathrm{g} / \mathrm{ml}[42,45])$ than those utilized for SPT and should be free of glycerine, in order to avoid falsepositive reactions. In the diagnosis of pollen allergy, several studies indicate that positive intradermal skin tests do not necessarily correlate with clinical symptoms $[22,42]$ whereas there is a very good correlation between SPT results and clinical allergy symptoms [25]. Thus, for the most part, SPT is preferable to intradermal testing, the latter being primarily used for Hymenoptera venom sensitivity, sensitization to medications, and where an allergen is considered historically relevant and in the circumstance that the SPT is negative [46]. Titration tests for Hymenoptera venoms are usually begun at concentrations of 1:1000 or after prior negative SPT using 1:100.

\section{Performance of the skin prick test}

\section{Preparation, precautions and contraindications}

SPT is safe with no reported fatalities in a 5-year USA study [47]. Because systemic allergic reactions and rare deaths have occurred associated with SPT [44,48], a physician or other health care professional and emergency equipment should be immediately available when such tests are performed. This is especially true when testing for a food or medication associated with the onset of anaphylaxis [49]. Systemic side effects are very unlikely for commercially available respiratory allergens [50]. Symptomatic asthma may be a risk factor for exacerbation of asthma associated with testing [44]. When reactions occur, they usually do so within 30 minutes of testing [50]. Measurement of specific IgE antibodies or titrated SPT are sometimes desirable for patients with severe anaphylaxis suspected from a specific allergen to which they are being tested, i.e., peanuts, tree nuts and shellfish. SPT should be performed with extra caution during the respective allergy season when the patient has allergic symptoms, or when baseline tryptase levels are elevated. The latter is a risk factor for anaphylaxis [51]. Likewise, patients, especially those taking a beta blocker, or less often, angiotensin converting enzyme (ACE)-inhibitor, may be at a higher risk because of less response to epinephrine that might be needed to treat a systemic allergic reaction. Relative contraindications for SPT include pregnancy, in view of a remote possibility of inducing a systemic allergic reaction that could induce uterine contractions or necessitate the use of epinephrine (thought to cause constriction of the umbilical artery [52]). SPTs are difficult to perform in patients with severe eczema, dermographism, or who are taking antihistamines or other medications such as certain antidepressants or calcineurin inhibitors (see Table 2) which can interfere with the proper interpretation of the test results. In vitro testing is recommended in these cases. The degree of skin test reactivity can be decreased in subjects with chronic illnesses such as renal failure, or cancer. Furthermore, chronic or acute UV-B radiation of the skin in the test area may reduce the wheal size from SPT [53].

The stability and expiration date of the allergen extracts utilized should always be checked. Test extracts should be stored at $+2^{\circ} \mathrm{C}-+8^{\circ} \mathrm{C}$ when not utilized to maintain stability. Histamine dihydrochloride $(10 \mathrm{mg} / \mathrm{ml}$ or $0.1 \%$ ) can be used as a positive control and diluent, as used in the test extracts, as a negative control. For oral allergy syndrome induced by certain foods, raw foods, i.e., fresh fruits and vegetables are preferably used. The skin of the fruit or vegetable is pricked and then the skin of the allergic patient, in order to determine skin test reactivity.

\section{SPT procedure}

Patients should be appropriately screened for asthma, and, where possible, discontinued on medications that interfere with test results, accentuate systemic allergic reactions or render patients less responsive to treatment with epinephrine. In patients with a history of severe systemic allergic reactions to food or drugs, an intravenous line for immediate circulatory access can be recommended. A peak flow of less than $70 \%$ in patients with asthma is a relative contraindication. Asthma should be controlled or testing deferred until control is achieved. When testing patients with a history of a severe systemic allergic reactions, skin test titration, first utilizing diluted extracts, is recommended. SPT should ideally be performed at least 4-6 weeks following a systemic allergic reaction, in particular, for Hymenoptera hypersensitivity, since test reactivity may be falsely negative for weeks following such a reaction $[24,54]$.

The location of each allergen can be marked with a pen or by using a test grid on the forearm to properly identify test results (Figure 1a). Tests should be applied to the volar aspect of the forearm, at least $2-3 \mathrm{~cm}$ from the wrist and the antecubital fossae [52]. The back can also be used for SPT, especially in infants. The skin on the back is more sensitive than the forearm which may result in larger wheals and thus possibly a greater 


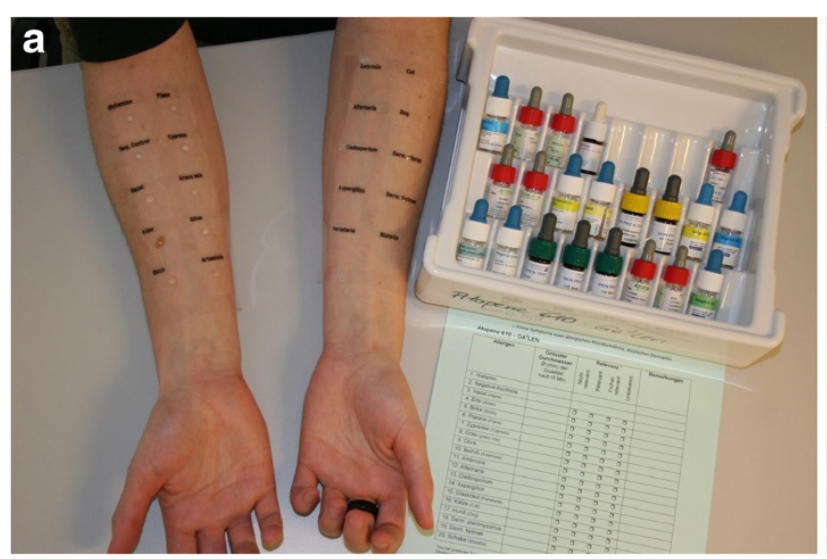

Figure 1 SPT procedures. (a) Preparation for skin prick test on forearm.

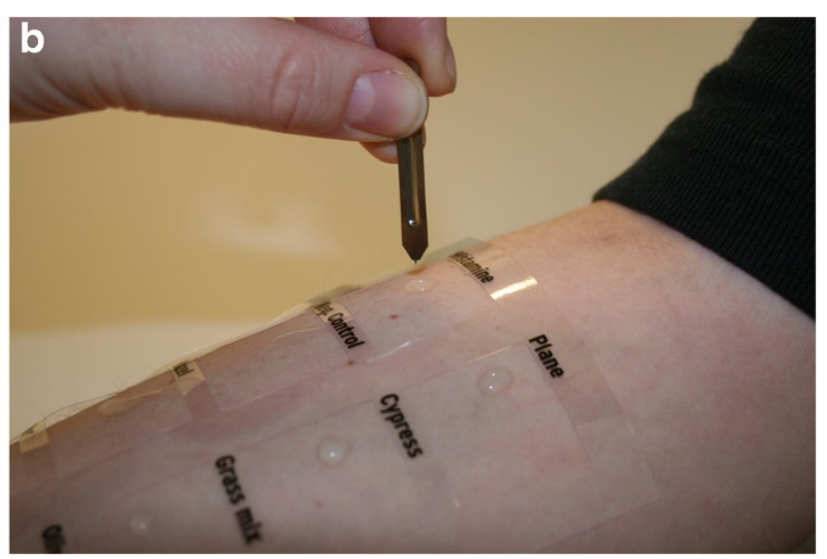

(b) Prick testing with lancet through a drop of allergen extract. number of positive test results [55]. The distance between two skin prick tests $(\geq 2 \mathrm{~cm})$ is critical to avoid false-positive reactions due to direct contamination of a nearby test or secondary to an axon reflex [55]. A drop of each test solution should be placed on the skin in identical order for each subject tested and immediately pricked.

A single-head metal lancet exhibits excellent reproducibility with few false-negative results and is thus the preferred testing instrument for SPT [56-58]. It is pressed through the drop of allergen extract and held against the skin for at least 1 second (Figure 1b), with equal pressure applied for each test. The epithelial layer of the skin should be penetrated without inducing bleeding, which can lead to false-positive results. A new lancet should be utilized for each allergen since wiping a previously used one between tests could result in crosscontamination from the previous allergen tested [59]. Wiping lancets also represents a potential risk factor for the healthcare professional performing the test. Excess solution from drops on the skin can be blotted using a clean tissue. It is important to assure that there is no cross-contamination between drops of different allergen extracts, i.e., that the drops do not run together. A timer, with an alarm, should be utilized so that all tests, including the histamine and negative control test results are read 15-20 minutes following application. Such timing for test results is recommended even though the histamine control can peak earlier at approximately $8-10$ minutes [60].

It is difficult or impossible to develop stable test extracts for certain allergens, in particular, certain foods, e.g., for skin testing to uncooked fruits and vegetables. A prick-to-prick technique is utilized, i.e., first pricking the fresh food with the lancet and then pricking the skin, to test for sensitization to such allergens when clinical allergy is suspected, in particular, oral allergy syndrome. Dry foods, e.g., nuts or cereal, can be pestled in saline and also utilized using the prick-to-prick technique. There can be differences in the degree of skin test reactivity depending on the variety of a fruit or vegetable, how ripe it is, and how it has been stored prior to its use [61].

\section{Assessing the SPT}

Positive and negative controls should be measured first. The negative control excludes the presence of dermographism which, when present, makes the tests difficult to interpret. The histamine control should be positive to make sure that the test materials are applied correctly and to exclude negative SPT results due to potentially interfering medications taken by the test subject (Table 2). The largest diameter of the wheal of each particular test is measured, a positive being a wheal of $\geq 3 \mathrm{~mm}$ [62] since the longest diameter is a better estimate of wheal surface area than the mean perpendicular diameters of a skin prick test above a certain value $\left(17 \mathrm{~mm}^{2}\right)$. The negative control is no longer used to deduct its size from the positive tests. Including the longest diameter of pseudopods does not increase sensitivity for determining the degree of sensitisation.

Since histamine reactivity in the skin varies among individuals, independent of skin test reactivity to allergens [52], the skin test results to allergens should not be related to the size of the histamine reaction [63]. The size of the wheal is not solely due to histamine as some subjects with positive SPT reaction show no significant histamine release to these allergens as assessed by microdialysis technique [64]. Reproducibility is greater when only the diameter of the wheal, and not the associated erythema, is measured $[65,66]$. In order to achieve a permanent record, the size of the wheal may be outlined with a pen, blotted onto a cellophane tape, and transcribed onto paper and/or stored electronically. 


\section{Clinical relevance}

The SPT confirms sensitization to a specific allergen, however, its clinical relevance must be interpreted based on the medical history and clinical symptoms (see Additional file 1: Table S3). Sometimes, conjunctival, intranasal, oral or even bronchial challenge provocation tests are performed to support clinically relevant sensitivity. The clinical relevance of SPT results varies, depending on the allergen utilized and the population tested. For example, sensitization to house dust mite occurs in some subjects in the absence of clinical relevance [4].

\section{Extracts}

Allergen extracts ideally should be standardized based on the content of the major and minor allergenic determinants since not all patients are allergic to each antigen within an individual extract. They should have batch-tobatch consistency and the skin test results should be comparable when the same extracts from different manufacturers are utilized. Since allergen extracts are biological mixtures containing a variety of different proteins, glycoproteins and polysaccharides, this is difficult to achieve. In fact, SPT results obtained with the same allergen with extracts from different manufacturers vary [67-72]. Thus, when SPT results are compared, the allergen extract utilized should be obtained from the same manufacturer. Likewise, effective allergen immunotherapy requires specified quantities of allergenic components in the extracts used for immunotherapy.

The fact that accurate standardization of extracts is of great importance for their quality has led manufacturers to implement extensive protocols for standardization. Each company uses its own in-house reference material and unique units to express potencies. Such variability among different manufacturers leads to an inability to compare different products and test results. However, since most major allergens of relevant allergens have been identified during the last several decades, the concept introduced is to quantitate the major allergens in each of the individual extracts. Such quantification will allow comparison between products by different manufacturers. In 2001, an EU funded project, the CREATE project, was introduced to encourage standardisation of allergen extracts based on their content of major allergen(s). The project evaluated the use of recombinant allergens as reference materials for major allergen measurements [73]. Another attempt to standardize extracts involved the development of recombinant allergen extracts. Even though some of these recombinant allergens show comparability to allergen extracts derived from source material [74-76], they only cover a limited number of allergens and are still under investigation.

Extracts should not contain preservatives which can cause false positive reactions, e.g., sodium merthiolate.
Nor should they be mixed with other allergens, e.g. house dust mite with dog dander extract. When testing with non-commercial allergens, there is a real need to use control tests in non-allergic subjects to compare the results with subjects who are allergic. For certain plant allergens, especially for fresh foods and vegetables, the prick-to-prick method is more reliable than using manufactured extracts [61].

The tight regulation of skin test extracts has made their production and registration problematic and costly for the pharmaceutical industry. This has led to gaps in the registration of specific extracts in certain European countries.

\section{Pan-European skin prick test panel for respiratory allergens}

The authors suggest that a standard SPT panel for inhalant allergens, based on the GA ${ }^{2}$ LEN study [3], be utilized throughout Europe. This panel includes the following 18 allergens: hazel (Corylus avellana), alder (Alnus incana), birch (Betula alba), plane (Platanus vulgaris), cypress (Cupressus sempervirens), grass mix (smooth meadow grass/Poa pratensis, cock's foot grass/Dactilis glomerata, perennial rye grass/Lolium perenne, timothy grass/Phleum pratense, meadow fescue/Festuca pratensis, meadow oat grass/Helictotrichon pretense), Olive (Olea europaea), mugwort (Artemisia vulgaris), ragweed (Ambrosia artemisiifolia), Alternaria alternata (tenuis), Cladosporium herbarum, Aspergillus fumigatus, Parietaria, cat, dog, Dermatophagoides pteronyssinus, Dermatophagoides farinae, and cockroach (Blatella germanica). Allergens can be supplemented as necessary for regional or for particular patient needs.

\section{Interpretation of SPT results}

SPT results should be appropriately interpreted based on clinical symptoms, medical history, and, where necessary, other test results (specific IgE antibody measurements) in order to assess possible allergy to a specific allergen. The probability of a given sensitization to be clinically relevant depends on the type of allergen and country where the patient lives [4]. The clinical relevance of any detected sensitization should be determined by an allergologist after taking a complete history and performing a physical examination. When SPT results and the history are inconclusive, provocation tests may help to determine the clinical relevance of the SPT sensitization, e.g., before initiation of a specific immunotherapy.

SPT is highly specific and sensitive, $70-95 \%$ and $80-97 \%$, respectively, to diagnose inhalant allergies [76]. The positive predictive value to diagnose allergic rhinitis based only on the clinical history is $77 \%$ for persistent allergy and $82-85 \%$ for intermittent seasonal allergy [17]. This increases to $97-99 \%$ if SPT is utilized [17]. 
The negative predictive value of a negative SPT and in vitro IgE antibody test for cat allergen are identical at $72-75 \%$ for cat allergy [42]. A negative SPT for Dermatophagoides pteronyssinus has a negative predictive value in older adults of $90 \%-95 \%$. However, the positive predictive value ranges from $29 \%$ to $43 \%$ in older subjects and $77 \%$ to $100 \%$ for younger subjects [23].

Sensitivity and specificity are lower for food allergens, ranging from $30-90 \%$ and $20-60 \%$, depending on the type of allergen and methods utilized, i.e. pricking with extracts vs. prick-to-prick techniques described earlier [77]. Double-blind placebo-controlled challenge studies in children demonstrate that SPT possesses a positive predictive value of $76 \%$ and $89 \%$ for clinical reactions to cow's milk and hen's egg, respectively [78].

The objective value of SPT for drug allergy depends on the tested drug. In most cases, a positive SPT makes drug allergy very probable; whereas a negative result does not necessarily indicate that the patient will not react on challenge to the drug [79]. However, for penicillin, the negative predictive value is high. In $98.5 \%$ of patients with a negative SPT, no type I allergy was observed upon challenge while the remaining $1.5 \%$ of patients had mild and self-limiting reactions, e.g., urticaria [80]. In many cases, intradermal testing is appropriate after negative SPT. Some drugs, e.g., muscle relaxants or opioids may cause SPT false-positive results. When evaluating patients for IgE-mediated drug allergy to antibiotics other than penicillin, SPT should be performed with the unadulterated pharmaceutical agent. Late readings (> 24h) of SPTs and especially intradermal skin tests are very valuable in the clarification of adverse drug reactions.

For suspected insect venom allergy, intradermal tests are the primary mode for detecting sensitization. SPT is performed prior to intradermal testing.

Sensitizations to aeroallergens, as measured by SPT, may precede symptomatic allergy. Prospective studies show that $30-60 \%$ of such subjects become allergic depending on the type of allergen tested and the time to follow-up $[81,82]$. Furthermore, sensitization can exist to an allergen that is no longer clinically relevant.

\section{SPT in epidemiologic studies}

Sensitization rates vary depending on the geographic region as measured in population-based and in patientbased studies like the European Community Respiratory Health Survey (ECHRS), the International Study of Asthma and Allergies in Childhood (ISAAC), and the GA ${ }^{2}$ LEN Pan-European skin prick test study. Exposure rates and genetic differences can explain some of these variations $[83,84]$. With increased human mobility, differences in exposure to various flora or alterations in the allergenicity of pollen, possibly caused by pollution
[85,86], and changes in sensitization occur over time [87]. Longitudinal studies investigating sensitization over time provide data on such trends [88,89].

The same allergen extracts and ideally even the same batches of extracts should be utilized when comparing a test result from one place to another or over time. For epidemiological studies, the standard prick test panel should be utilized to ensure comparability with the $\mathrm{GA}^{2} \mathrm{LEN}$ study results (see Table 1; [3]). Distribution of standard operating procedures for both technical aspects and data collection assures the highest degree of comparability. Studies of allergic sensitization should take place over an extended period of time, ideally, a year, since (i) skin test reactivity increases during the pollen season [90] and (ii) allergic individuals tend to seek care when they have symptoms. This can skew detected prevalence of sensitization in such studies. It is also important to note the seasonal differences of various allergens based on geographic locations which can further distort sensitization rates between countries.

\section{Future directions to use skin tests for allergy diagnosis}

More than 1,800 allergenic molecules are identified (http://www.allergome.org/script/statistic.php; [91]). The use of recombinant allergen molecules for SPT should improve sensitivity and standardization of SPT by reducing non-specific reactivity due to irritant compounds contained in biologically derived extracts, in particular, food extracts [92]. New in vitro techniques using recombinant molecules and micro-technology may permit testing of hundreds of compounds simultaneously, thus improving diagnostic possibilities and potentially even eliminating the need for skin testing [93].

\section{Needs for further research}

Further studies are needed to (1) compare extracts from different manufacturers, (2) investigate intra subject variability, and (3) determine the relevance of SPT for pan-allergens. Since new allergens are being identified in Europe, e.g., acerola (Malpighia glabra), and others are becoming more prevalent, e.g., Lepidoglyphus destructor, new studies should also investigate the relevance of these allergens.

\section{Conclusion and outlook}

There is general agreement that the core diagnostic test for type I immediate allergy, i.e. the SPT, should be further standardized to include standardized procedures and allergen panels. Additional allergens can be added to this "core", when indicated. Such standards are likely to: (1) improve the quality of patient diagnosis and care, and (2) reduce variability of results and thus make test 
results comparable. Further studies are necessary to define worldwide standards for allergen extracts.

\section{Additional file}

Additional file 1: Table S3. Skin prick test panel - inhalant allergens.

\section{Abbreviations}

GA²LEN: Global Allergy and Asthma European Network; IgE: Immunoglobuline E; SIT: Specific immunotherapy; SPT: Skin prick test; mm: millimetre; RAST: Radioallergosorbent test.

\section{Competing interests}

No conflicts of interest exist for any of the authors.

\section{Authors' contributions}

Conceived and designed the European SPT study: LMH, MB, GB, UD, SD, WF, $M G, T H, A T B, S W$. Wrote the manuscript: LMH, RL, AM, KCB. Critically reviewed and revised the manuscript: $M B, G B, U D, S D, W F, M G, T H, A T B, S W$, HM. Final language editing: SD. Agreement with manuscript and conclusions: all. Designed the figures and tables: LMH, RL. All authors read and approved the final manuscript.

\section{Authors' information}

Lucie Heinzerling, Karl-Christian Bergmann, Megon Bresciani, Guido Burbach, Ulf Darsow, Stephen Durham, Wytske Fokkens, Mark Gjomarkaj, Tari Haahtela, Ana Todo Bom, Stefan Wöhrl: GA²LEN member.

\section{Author details}

'Department of Dermatology, University Hospital Erlangen, 91054 Erlangen, Germany. ${ }^{2}$ Board Member of the EAACl Allergy Diagnosis Interest Group, IDI-IRCCS, Center for Molecular Allergology, Rome, Italy. ${ }^{3}$ Department of Dermatology and Allergy, Charité Universitätsmedizin-Berlin, Berlin, Germany. ${ }^{4}$ Consiglio Nazionale delle Ricerche, Rome, Italy. ${ }^{5}$ Department of Dermatology and Allergy Biederstein and Division of Environmental Dermatology and Center of Allergy and Environment (ZAUM), Technical University, Munich, Germany. ${ }^{6}$ Department of Respiratory Medicine, Royal Brompton Hospital, London, UK. 'Department of Otorhinolaryngology, Academic Medical Centre, Amsterdam, Netherlands. ${ }^{8}$ Consiglio Nazionale delle Ricerche, Palermo, Italy. ${ }^{9}$ Skin and Allergy Hospital, University Central Hospital, Helsinki, Finland. ${ }^{10}$ ImunoAlergologia, Coimbra University, Coimbra, Portugal. ${ }^{11}$ Department of Dermatology, Medical University of Vienna, Vienna, Austria \& Floridsdorf Allergy Centre (FAZ), Vienna, Austria. ${ }^{12}$ Department of Dermatology, University of California, San Francisco, California, USA. ${ }^{13}$ Division of Allergy \& Immunology, University of South Florida College of Medicine, Tampa, Florida, USA.

Received: 20 September 2012 Accepted: 18 January 2013 Published: 1 February 2013

\section{References}

1. EBRUSTER H: The prick test, a recent cutaneous test for the diagnosis of allergic disorders. Wien Klin Wochenschr 1959, 71:551-554.

2. Heinzerling L, Frew AJ, Bindslev-Jensen C, Bonini S, Bousquet J, Bresciani M, Carlsen KH, Van CP, Darsow U, Fokkens WJ, Haahtela T, Van HH, Jessberger B, Kowalski ML, Kopp T, Lahoz CN, Lodrup Carlsen KC, Papadopoulos NG, Ring J, Schmid-Grendelmeier P, Vignola AM, Wohrl S, Zuberbier T: Standard skin prick testing and sensitization to inhalant allergens across Europe--a survey from the GALEN network. Allergy 2005, 60(10):1287-1300.

3. Heinzerling LM, Burbach GJ, Edenharter G, Bachert C, Bindslev-Jensen C, Bonini S, Bousquet J, Bousquet-Rouanet L, Bousquet PJ, Bresciani M, Bruno A, Burney P, Canonica GW, Darsow U, Demoly P, Durham S, Fokkens WJ, Giavi S, Gjomarkaj M, Gramiccioni C, Haahtela T, Kowalski ML, Magyar P, Murakozi G, Orosz M, Papadopoulos NG, Rohnelt C, Stingl G, Todo-Bom A, Von ME, Wiesner A, Wohrl S, Zuberbier T: GA(2)LEN skin test study I: GA(2) LEN harmonization of skin prick testing: novel sensitization patterns for inhalant allergens in Europe. Allergy 2009, 64(10):1498-1506.

4. Burbach GJ, Heinzerling LM, Edenharter G, Bachert C, Bindslev-Jensen C, Bonini S, Bousquet J, Bousquet-Rouanet L, Bousquet PJ, Bresciani M, Bruno
A, Canonica GW, Darsow U, Demoly P, Durham S, Fokkens WJ, Giavi S, Gjomarkaj M, Gramiccioni C, Haahtela T, Kowalski ML, Magyar P, Murakozi G, Orosz M, Papadopoulos NG, Rohnelt C, Stingl G, Todo-Bom A, Von ME, Wiesner A, Wohrl S, Zuberbier T: GA(2)LEN skin test study II: clinical relevance of inhalant allergen sensitizations in Europe. Allergy 2009, 64(10):1507-1515.

5. Bousquet J, Lebel B, Dhivert H, Bataille Y, Martinot B, Michel FB: Nasal challenge with pollen grains, skin-prick tests and specific lgE in patients with grass pollen allergy. Clin Allergy 1987, 17(6):529-536.

6. Blackley C: Hay fever: its causes, treatment and effective prevention; experimental researches. London: Baillieres, Tindal \& Cox; 1880.

7. Hug K, Yawalkar N, Helbling A, Pichler WJ: Scratch-patch and patch testing in drug allergy-an assessment of specificity. J Investig Allergol Clin Immunol 2003, 13(1):12-19.

8. Ricci G, Capelli M, Miniero R, Menna G, Zannarini L, Dillon P, Masi M: A comparison of different allergometric tests, skin prick test, Pharmacia UniCAP and ADVIA Centaur, for diagnosis of allergic diseases in children. Allergy 2003, 58(1):38-45.

9. Pumhirun P, Jane-Trakoonroj S, Wasuwat P: Comparison of in vitro assay for specific lgE and skin prick test with intradermal test in patients with allergic rhinitis. Asian Pac J Allergy Immunol 2000, 18(3):157-160.

10. Liccardi G, Dente B, Triggiani M, Russo M, Diamare F, Massari A, Pinzarrone R, D'ssanto R, Letizia M, D'Amato M, D'Amato G: A multicenter evaluation of the CARLA system for the measurement of specific lgE antibodies vs. other different methods and skin prick tests. J Investig Allergol Clin Immunol 2002, 12(4):235-241.

11. Hill DJ, Heine RG, Hosking CS: The diagnostic value of skin prick testing in children with food allergy. Pediatr Allergy Immunol 2004, 15(5):435-441.

12. Chung BY, Kim HO, Park CW, Lee CH: Diagnostic usefulness of the serumspecific ige, the skin prick test and the atopy patch test compared with that of the oral food challenge test. Ann Dermatol 2010, 22(4):404-411.

13. Ten RM, Klein JS, Frigas E: Allergy skin testing. Mayo Clin Proc 1995, 70(8):783-784.

14. Van der Zee JS, De GH, Van SP, Jansen HM, Aalberse RC: Discrepancies between the skin test and IgE antibody assays: study of histamine release, complement activation in vitro, and occurrence of allergenspecific lgG. J Allergy Clin Immunol 1988, 82(2):270-281.

15. Bousquet J, Chanez P. Chanal I, Michel FB: Comparison between RAST and Pharmacia CAP system: a new automated specific IgE assay. J Allergy Clin Immunol 1990, 85(6):1039-1043.

16. Ewan PW, Coote D: Evaluation of a capsulated hydrophilic carrier polymer (the ImmunoCAP) for measurement of specific lgE antibodies. Allergy 1990, 45(1):22-29.

17. Crobach MJ, Hermans J, Kaptein AA, Ridderikhoff J, Petri H, Mulder JD: The diagnosis of allergic rhinitis: how to combine the medical history with the results of radioallergosorbent tests and skin prick tests. Scand J Prim Health Care 1998, 16(1):30-36.

18. Wohrl S, Vigl K, Zehetmayer S, Hiller R, Jarisch R, Prinz M, Stingl G, Kopp T: The performance of a component-based allergen-microarray in clinical practice. Allergy 2006, 61(5):633-639.

19. Bernstein IL, Li JT, Bernstein DI, Hamilton R, Spector SL, Tan R, Sicherer S, Golden DB, Khan DA, Nicklas RA, Portnoy JM, Blessing-Moore J, Cox L, Lang DM, Oppenheimer J, Randolph CC, Schuller DE, Tilles SA, Wallace DV, Levetin E, Weber R: Allergy diagnostic testing: an updated practice parameter. Ann Allergy Asthma Immunol 2008, 100(3 Suppl 3):S1-S148.

20. Nolte H, DuBuske LM: Performance characteristics of a new automated enzyme immunoassay for the measurement of allergen-specific lgE. Summary of the probability outcomes comparing results of allergen skin testing to results obtained with the HYTEC system and CAP system. Ann Allergy Asthma Immunol 1997, 79(1):27-34.

21. Williams PB, Dolen WK, Koepke JW, Selner JC: Comparison of skin testing and three in vitro assays for specific lgE in the clinical evaluation of immediate hypersensitivity. Ann Allergy 1992, 68(1):35-45.

22. Tschopp JM, Sistek D, Schindler C, Leuenberger P, Perruchoud AP, Wuthrich B, Brutsche M, Zellweger JP, Karrer W, Brandli O: Current allergic asthma and rhinitis: diagnostic efficiency of three commonly used atopic markers (IgE, skin prick tests, and Phadiatop). Results from 8329 randomized adults from the SAPALDIA Study. Swiss Study on Air Pollution and Lung Diseases in Adults. Allergy 1998, 53(6):608-613.

23. King MJ, Tamulis T, Lockey RF: Prick puncture skin tests and serum specific $\lg E$ as predictors of nasal challenge response to 
dermatophagoides pteronyssinus in older adults. Ann Allergy Asthma Immunol 2008, 101(1):12-17.

24. Goldberg A, Confino-Cohen R: Timing of venom skin tests and lgE determinations after insect sting anaphylaxis. J Allergy Clin Immunol 1997, 100(2):182-184.

25. Dreborg S: The skin prick test in the diagnosis of atopic allergy. J Am Acad Dermatol 1989, 21(4 Pt 2):820-821.

26. Devillier $\mathrm{P}$, Bousquet J: Inhibition of the histamine-induced weal and flare response: a valid surrogate measure for antihistamine clinical efficacy? Clin Exp Allergy 2007, 37(3):400-414.

27. Hammarlund A, Olsson P, Pipkorn U: Blood flow in histamine- and allergeninduced weal and flare responses, effects of an $\mathrm{H} 1$ antagonist, alphaadrenoceptor agonist and a topical glucocorticoid. Allergy 1990, 45(1):64-70.

28. Pipkorn U, Hammarlund A, Enerback L: Prolonged treatment with topical glucocorticoids results in an inhibition of the allergen-induced weal-andflare response and a reduction in skin mast cell numbers and histamine content. Clin Exp Allergy 1989, 19(1):19-25.

29. Gradman J, Wolthers OD: Suppressive effects of topical mometasone furoate and tacrolimus on skin prick testing in children. Pediatr Dermatol 2008, 25(2):269-270.

30. Hammarlund A, Pipkorn U, Enerback L: Mast cells, tissue histamine and eosinophils in early- and late-phase skin reactions: effects of a single dose of prednisolone. Int Arch Allergy Appl Immunol 1990, 93(2-3):171-177.

31. Des RA, Paradis L, Bougeard YH, Godard P, Bousquet J, Chanez P: Longterm oral corticosteroid therapy does not alter the results of immediatetype allergy skin prick tests. J Allergy Clin Immunol 1996, 98(3):522-527.

32. Olson $\mathrm{R}$, Karpink MH, Shelanski S, Atkins PC, Zweiman B: Skin reactivity to codeine and histamine during prolonged corticosteroid therapy. J Allergy Clin Immunol 1990, 86(2):153-159.

33. Noga $\mathrm{O}$, Hanf $\mathrm{G}$, Kunkel $\mathrm{G}$ : Immunological and clinical changes in allergic asthmatics following treatment with omalizumab. Int Arch Allergy Immunol 2003, 131(1):46-52.

34. Cuhadaroglu C, Erelel M, Kiyan E, Ece T, Erkan F: Role of Zafirlukast on skin prick test. Allergol Immunopathol (Madr ) 2001, 29(2):66-68.

35. Hill SL III, Krouse JH: The effects of montelukast on intradermal wheal and flare. Otolaryngol Head Neck Surg 2003, 129(3):199-203.

36. Munro CS, Higgins EM, Marks JM, Daly BM, Friedmann PS, Shuster S: Cyclosporin A in atopic dermatitis: therapeutic response is dissociated from effects on allergic reactions. Br J Dermatol 1991, 124(1):43-48

37. Spector SL: Effect of a selective beta 2 adrenergic agonist and theophylline on skin test reactivity and cardiovascular parameters. J Allergy Clin Immunol 1979, 64(1):23-28.

38. Rao KS, Menon PK, Hilman BC, Sebastian CS, Bairnsfather L: Duration of the suppressive effect of tricyclic antidepressants on histamine-induced wheal-and-flare reactions in human skin. J Allergy Clin Immunol 1988, 82(5 Pt 1):752-757.

39. Isik SR, Celikel S, Karakaya G, Ulug B, Kalyoncu AF: The effects of antidepressants on the results of skin prick tests used in the diagnosis of allergic diseases. Int Arch Allergy Immunol 2011, 154(1):63-68.

40. Abramowitz PW, Perez MM, Johnson CE, McLean JA: Effect of theophylline, terbutaline, and their combination on the immediate hypersensitivity skin-test reaction. J Allergy Clin Immunol 1980, 66(2):123-128.

41. Petersen $\sqcup$, Skov PS: Effect of terbutaline and bambuterol on immediatetype allergic skin responses and mediator release in human skin. Inflamm Res 2003, 52(9):372-377.

42. Wood RA, Phipatanakul W, Hamilton RG, Eggleston PA: A comparison of skin prick tests, intradermal skin tests, and RASTs in the diagnosis of cat allergy. J Allergy Clin Immunol 1999, 103(5 Pt 1):773-779.

43. Riezzo I, Bello S, Neri M, Turillazzi E, Fineschi V: Ceftriaxone intradermal test-related fatal anaphylactic shock: a medico-legal nightmare. Allergy 2010, 65(1):130-131.

44. Lockey RF, Benedict LM, Turkeltaub PC, Bukantz SC: Fatalities from immunotherapy (IT) and skin testing (ST). J Allergy Clin Immunol 1987, 79(4):660-677

45. Fisher MM, Bowey $\mathrm{CJ}$ : Intradermal compared with prick testing in the diagnosis of anaesthetic allergy. Br J Anaesth 1997, 79(1):59-63.

46. Anderson JA: Allergic reactions to drugs and biological agents. JAMA 1992, 268(20):2844-2857.
47. Reid MJ, Lockey RF, Turkeltaub PC, Platts-Mills TA: Survey of fatalities from skin testing and immunotherapy 1985-1989. J Allergy Clin Immunol 1993, 92(1 Pt 1):6-15.

48. Novembre E, Bernardini R, Bertini G, Massai G, Vierucci A: Skin-prick-testinduced anaphylaxis. Allergy 1995, 50(6):511-513.

49. Turkeltaub PC, Gergen PJ: The risk of adverse reactions from percutaneous prick-puncture allergen skin testing, venipuncture, and body measurements: data from the second National Health and Nutrition Examination Survey 1976-80 (NHANES II). J Allergy Clin Immunol 1989, 84(6 Pt 1):886-890.

50. Lüderitz-Püchel U, Keller-Stanislawski B, Haustein D: Neubewertung des Risikos von Test- und Therapieallergenen. 44th edition.; 2001:709-718.

51. Rueff F, Przybilla B, Bilo MB, Muller U, Scheipl F, Aberer W, Birnbaum J, Bodzenta-Lukaszyk A, Bonifazi F, Bucher C, Campi P, Darsow U, Egger C, Haeberli G, Hawranek T, Korner M, Kucharewicz I, Kuchenhoff H, Lang R, Quercia O, Reider N, Severino M, Sticherling M, Sturm GJ, Wuthrich B: Predictors of severe systemic anaphylactic reactions in patients with Hymenoptera venom allergy: importance of baseline serum tryptase-a study of the European Academy of Allergology and Clinical Immunology Interest Group on Insect Venom Hypersensitivity. J Allergy Clin Immunol 2009, 124(5):1047-1054.

52. Bernstein IL, Storms WW: Practice parameters for allergy diagnostic testing. Joint Task Force on Practice Parameters for the Diagnosis and Treatment of Asthma.The American Academy of Allergy, Asthma and Immunology and the American College of Allergy, Asthma and Immunology. Ann Allergy Asthma Immunol 1995, 75(6 Pt 2):543-625.

53. Vocks E, Stander K, Rakoski J, Ring J: Suppression of immediate-type hypersensitivity elicitation in the skin prick test by ultraviolet $B$ irradiation. Photodermatol Photoimmunol Photomed 1999, 15(6):236-240.

54. Rueff F, Bergmann KC, Brockow K, Fuchs T, Grubl A, Jung K, Klimek L, Musken H, Pfaar O, Przybilla B, Sitter H, Wehrmann W: [Skin tests for diagnostics of allergic immediate-type reactions. Guideline of the German Society for Allergology and Clinical Immunology]. Pneumologie 2011, 65(8):484-495.

55. Nelson HS, Knoetzer J, Bucher B: Effect of distance between sites and region of the body on results of skin prick tests. J Allergy Clin Immunol 1996, 97(2):596-601.

56. Carr WW, Martin B, Howard RS, Cox L, Borish L: Comparison of test devices for skin prick testing. J Allergy Clin Immunol 2005, 116(2):341-346.

57. Nelson HS, Kolehmainen C, Lahr J, Murphy J, Buchmeier A: A comparison of multiheaded devices for allergy skin testing. J Allergy Clin Immunol 2004, 113(6):1218-1219.

58. Demoly P, Bousquet J, Manderscheid JC, Dreborg S, Dhivert H, Michel FB: Precision of skin prick and puncture tests with nine methods. J Allergy Clin Immunol 1991, 88(5):758-762.

59. Piette $V$, Bourret $E$, Bousquet J, Demoly P: Prick tests to aeroallergens: is it possible simply to wipe the device between tests? Allergy 2002, 57 (10):940-942.

60. Oppenheimer J, Nelson HS: Skin testing. Ann Allergy Asthma Immunol 2006, 96(2 Suppl 1):S6-S12

61. Henzgen M, Ballmer-Weber BK, Erdmann S, Fuchs T, Kleine-Tebbe J, Lepp U, Niggemann B, Raithel M, Reese I, Saloga J, Vieths S, Zuberbier T, Werfel T: Skin testing with food allergens. Guideline of the German Society of Allergology and Clinical Immunology (DGAKI), the Physicians' Association of German Allergologists (ADA) and the Society of Pediatric Allergology (GPA) together with the Swiss Society of Allergology. J Dtsch Dermatol Ges 2008, 6(11):983-988.

62. Konstantinou GN, Bousquet PJ, Zuberbier T, Papadopoulos NG: The longest wheal diameter is the optimal measurement for the evaluation of skin prick tests. Int Arch Allergy Immunol 2010, 151(4):343-345.

63. De Weck AL, Derer T: Critical evaluation of the use of skin tests and cellular tests in standardization of allergens. Arb Paul Ehrlich Inst Bundesamt Sera Impfstoffe Frankf A M 1994, 87:89-114.

64. Horsmanheimo L, Harvima IT, Harvima RJ, Ylonen J, Naukkarinen A, Horsmanheimo M: Histamine release in skin monitored with the microdialysis technique does not correlate with the weal size induced by cow allergen. Br J Dermatol 1996, 134(1):94-100.

65. Vohlonen I, Terho EO, Koivikko A, Vanto T, Holmen A, Heinonen OP: Reproducibility of the skin prick test. Allergy 1989, 44(8):525-531. 
66. Dirksen A, Malling HJ, Mosbech $H$, Soborg M, Biering I: HEP versus PNU standardization of allergen extracts in skin prick testing. A comparative randomized in vivo study. Allergy 1985, 40(8):620-624.

67. Mari A, Schneider P, Wally V, Breitenbach M, Simon-Nobbe B: Sensitization to fungi: epidemiology, comparative skin tests, and IgE reactivity of fungal extracts. Clin Exp Allergy 2003, 33(10):1429-1438

68. Rhodius R, Wickens K, Cheng S, Crane J: A comparison of two skin test methodologies and allergens from two different manufacturers. Ann Allergy Asthma Immunol 2002, 88(4):374-379.

69. Nielsen NH, Dirksen A, Mosbech H, Launbjerg J, Biering I, Soborg M: Skin prick testing with standardized extracts from 3 different manufacturers. A comparative randomized study. Allergol Immunopathol (Madr) 1992, 20(6):246-248.

70. Eichler I, Gotz M, Jarisch R, Eichler HG, Moss R: Reproducibility of skin prick testing with allergen extracts from different manufacturers. Allergy 1988, 43(6):458-463.

71. Focke M, Marth K, Flicker S, Valenta R: Heterogeneity of commercial timothy grass pollen extracts. Clin Exp Allergy 2008, 38(8):1400-1408.

72. Focke M, Marth K, Valenta R: Molecular composition and biological activity of commercial birch pollen allergen extracts. Eur J Clin Invest 2009, 39(5):429-436

73. Van RR, Chapman MD, Ferreira F, Vieths S, Bryan D, Cromwell O, Villalba M, Durham SR, Becker WM, Aalbers M, Andre C, Barber D, Cistero BA, Custovic A, Didierlaurent A, Dolman C, Dorpema JW, Di FG, Eberhardt F, Fernandez CE, Fernandez RM, Fiebig H, Focke M, Fotisch K, Gadermaier G, Das RG, Gonzalez ME, Himly M, Kinaciyan T, Knulst AC, Kroon AM, Lepp U, Marco FM, Mari A, Moingeon P, Monsalve R, Neubauer A, Notten S, Ooievaar-de HP, Pauli G, Pini C, Purohit A, Quiralte J, Rak S, Raulf-Heimsoth M, San Miguel Moncin MM, Simpson B, Tsay A, Vailes L, Wallner M, Weber B: The CREATE project: development of certified reference materials for allergenic products and validation of methods for their quantification. Allergy 2008, 63(3):310-326.

74. Pauli G, Oster JP, Deviller P, Heiss S, Bessot JC, Susani M, Ferreira F, Kraft D, Valenta R: Skin testing with recombinant allergens $r$ Bet $\vee 1$ and birch profilin, rBet v 2: diagnostic value for birch pollen and associated allergies. J Allergy Clin Immunol 1996, 97(5):1100-1109.

75. Schmid-Grendelmeier $P$, Crameri R: Recombinant allergens for skin testing. Int Arch Allergy Immunol 2001, 125(2):96-111.

76. Demoly P, Bousquet J, Romano A: In vivo methods for the study of allergy. In Middleton's Allergy - Principles and Practice. 6th edition. Edited by Adkinson NJ, Yunginger J, Busse W, Bochner B, Holgate S, Simons F. Philadelphia: Mosby; 2003:430-439.

77. Rance F, Juchet A, Bremont F, Dutau G: Correlations between skin prick tests using commercial extracts and fresh foods, specific lgE, and food challenges. Allergy 1997, 52(10):1031-1035.

78. Verstege A, Mehl A, Rolinck-Werninghaus C, Staden U, Nocon M, Beyer K, Niggemann B: The predictive value of the skin prick test weal size for the outcome of oral food challenges. Clin Exp Allergy 2005, 35(9):1220-1226.

79. Gruchalla R: Understanding drug allergies. J Allergy Clin Immunol 2000, 105(6 Pt 2):S637-S644.

80. Salkind AR, Cuddy PG, Foxworth JW: The rational clinical examination. Is this patient allergic to penicillin? An evidence-based analysis of the likelihood of penicillin allergy. JAMA 2001, 285(19):2498-2505.

81. Hagy GW, Settipane GA: Prognosis of positive allergy skin tests in an asymptomatic population. A three year follow-up of college students. J Allergy Clin Immunol 1971, 48(4):200-211.

82. Horak F: The allergen quick test: a simple allergy test to prove existing sensitization. Arch Otorhinolaryngol 1985, 242(3):233-238.

83. van den Oord RA, Sheikh A: Filaggrin gene defects and risk of developing allergic sensitisation and allergic disorders: systematic review and metaanalysis. Bmj 2009, 339:b2433.

84. Bottema RW, Reijmerink NE, Kerkhof M, Koppelman GH, Stelma FF, Gerritsen J, Thijs C, Brunekreef B, van Schayck CP, Postma DS: Interleukin 13, CD14, pet and tobacco smoke influence atopy in three Dutch cohorts: the allergenic study. Eur Respir J 2008, 32(3):593-602.

85. Cortegano I, Civantos E, Aceituno E, Del MA, Lopez E, Lombardero M, Del PV, Lahoz C: Cloning and expression of a major allergen from Cupressus arizonica pollen, Cup a 3, a PR-5 protein expressed under polluted environment. Allergy 2004, 59(5):485-490.
86. Bryce M, Drews O, Schenk MF, Menzel A, Estrella N, Weichenmeier I, Smulders MJ, Buters J, Ring J, Gorg A, Behrendt H, Traidl-Hoffmann C: Impact of urbanization on the proteome of birch pollen and its chemotactic activity on human granulocytes. Int Arch Allergy Immunol 2010, 151(1):46-55.

87. Burbach GJ, Heinzerling LM, Rohnelt C, Bergmann KC, Behrendt $H_{\text {, }}$ Zuberbier T: Ragweed sensitization in Europe - GA(2)LEN study suggests increasing prevalence. Allergy 2009, 64(4):664-665.

88. Shaaban R, Zureik M, Soussan D, Neukirch C, Heinrich J, Sunyer J, Wjst M, Cerveri I, Pin I, Bousquet J, Jarvis D, Burney PG, Neukirch F, Leynaert B: Rhinitis and onset of asthma: a longitudinal population-based study. Lancet 2008, 372(9643):1049-1057.

89. Linneberg A, Jorgensen T, Nielsen NH, Madsen F, Frolund L, Dirksen A: The prevalence of skin-test-positive allergic rhinitis in Danish adults: two cross-sectional surveys 8 years apart. The Copenhagen Allergy Study. Allergy 2000, 55(8):767-772.

90. Oppenheimer JJ, Nelson HS: Seasonal variation in immediate skin test reactions. Ann Allergy 1993, 71(3):227-229.

91. Mari A, Rasi C, Palazzo P, Scala E: Allergen databases: current status and perspectives. Curr Allergy Asthma Rep 2009, 9(5):376-383.

92. Asturias JA, Ibarrola I, Ferrer A, Andreu C, Lopez-Pascual E, Quiralte J, Florido $F$, Martinez A: Diagnosis of Alternaria alternata sensitization with natural and recombinant Alt a 1 allergens. J Allergy Clin Immunol 2005, 115(6):1210-1217.

93. Mari A, Alessandri C, Bernardi ML, Ferrara R, Scala E, Zennaro D: Microarrayed allergen molecules for the diagnosis of allergic diseases. Curr Allergy Asthma Rep 2010, 10(5):357-364.

doi:10.1186/2045-7022-3-3

Cite this article as: Heinzerling et al:: The skin prick test - European standards. Clinical and Translational Allergy 2013 3:3.

\section{Submit your next manuscript to BioMed Central and take full advantage of:}

- Convenient online submission

- Thorough peer review

- No space constraints or color figure charges

- Immediate publication on acceptance

- Inclusion in PubMed, CAS, Scopus and Google Scholar

- Research which is freely available for redistribution 